\title{
Negative Impacts of Plastic Pollution A Major Threat To Our Environment
}

\author{
Sivakumar $\mathrm{K}^{*}$ \\ Department of Botany, Annamalai University, India
}

Submission: April 18, 2018; Published: August 02, 2018

Corresponding author: Sivakumar K, Division of Algal, Biotechnology, Department of Botany, Annamalai University, Annamalainagar - 608002 , Tamil Nadu, India, Email: kshivam69@gmail.com

\begin{abstract}
Intensive investigation was made on certain ponds of Chidambaram taluk. The present studies are confined to Chlorophyceae and Bacilariophyceae. Studies revealed that the Chlorophyceae is represented by 6 orders i.e., Chlorococcales (19 genera and 41 species), Volvocales ( 3 genera and 3 species), Chaetophorales (2 genera), Oedogoniales (Oedogonium; 2 species, Bulbochaete; 1 species), 2 Zygnemales (Spirogyra; 4 species) and Conjugales ( 6 genera and 18 species), constituting 35 genera and 76 species. Chloroccales is most dominant group, representing 35 genera and 76 species. Chloroccales is most dominant group, representing $40 \%$ of the total reported green algal population were more followed by Bacilariophyceae members. It has been observed that the green algal population exhibited remarkable variations and fluctations both qualitatively and quantitatively during different seasons and months of year. The ecological characteristics of habitat water ranged remarkably i.e., $\mathrm{pH}(9-10)$, temperature $\left(38-40{ }^{\circ} \mathrm{C}\right)$, dissolved oxygen $(5-11 \mathrm{mg} / \mathrm{l})$, carbondioxide $(6-12 \mathrm{mg} / \mathrm{l}), \mathrm{HCO}_{3}-(80-100 \mathrm{mg} / \mathrm{l}), \mathrm{Ca}^{++}(15-$ $25 \mathrm{mg} / \mathrm{l}), \mathrm{Mg}^{++}(4-15 \mathrm{mg} / \mathrm{l})$ and $\mathrm{Cl}-(0.70-1.75 \mathrm{mg} / \mathrm{l})$. Present studied water body is alkaline in nature with continuous operation of carbondioxidecarbonate-bicarbonate systems. Successional changes in species composition revealed that order Chlorococcales dominated other groups in winter season, while during monsoons Conjugales, Oedogoniales, Zygnemales and Chlorococcales dominated, where as species composition remained uniform with respect to all the groups of green algae during summer. Present studies revealed that the various taxa belonging to green algae namely Scenedesmus, Cosmarium, Ankistrodemus, Oedogonium, Spirogyra, etc., being important not only as the basic food components of various herbivores fish population inhabiting the pond but can be exploited in mass culturing for the future development of aquaculture in the region. Occurrence of pollution tolerant species i.e., Spirogyra, Closterium, Chroococcus, Scenedesmus and Pediastrum etc., some of the Bacillariophyceae members were made by scanning electron micrograph to under the endomorpholigcal features indicates that the pond is gradually progressing towards eutrophication, which has been discussed in the present communication. Plastic is non-compostable and can take centuries to decompose and the real impact of plastic (polythene) litter is being felt in both aquatic and terrestrial environments. The floating polythene materials in open waters can significantly change the aquatic communities such as fishes, birds, mammals and turtles. When plastics are eaten and while they enter the animal's digestive tract, it causes severe digestive problems.
\end{abstract}

Keywords: Physico-chemical parameters; Phytoplankton; Polythene bag; Heavy metals; Alteration of chromosomes

\section{Introduction}

Freshwater is the most precious gift of nature to human kind since no life is possible water. All living organisms' microbes, plants, animals and human require water for survival and development. However, with the total freshwater available for human consumption essentially unchanged, the human population has been constantly increasing resulting in a rapid increase in water consumption and consequently water scarcity in many parts of the world. Phytoplankton, being the primary producers in the food chain of freshwater ecosystem, play a key role in bio-monitoring the ecological disturbances caused by a number of physico-chemical factors, pond morphometry, sewage pollutants and other anthropogenic factors. Study of planktonic diversity contributes to an understanding of the environmental status of a water body.
The presence of polythene in the environment causes serious problems in wastewater treatment plants and pollution of groundwater and surface water leading to long term environmental, economic and waste management problems. The present work is a small initiative to find if algae can degrade plastic dumped in the water bodies. Each year approximately 140 million tons of synthetic polymers are produced [1]. Global plastic production has increased exponentially since the 1960s, to around 299 million tones in 2013 and a large proportion of which is ending up in entering aquatic systems as pollution and taking many several years to degrade. A general estimate of worldwide plastic waste generation is about 57 million tons [2]. Every year 25 million tons of synthetic plastic are being accumulated in the sea coasts and terrestrial environment. Microplastics are one of the most widespread and potentially 
damaging aquatic stressors emerging from the growth of consumer society in recent decades. Polyethylene is the one of the most abundant commercially produced synthetic polymers. LDPE (Low-Density Polyethylene) constitutes $64 \%$ of the total synthetic plastic as it is being used in huge quantity for the manufacture of bottles, carry bags, disposable articles, garbage containers, margarine tubs, milk jugs and water pipes.

Polyethylene is very resistant to biodegradation due to its high hydrophobicity and its long carbon chains (Contat-Rodrigo \& Ribes Greus, 2002). Under normal condition, it takes more than 10 decades to mineralize the polymers [3]. The physiochemical behaviour of plastic gives rise to unique pollution problem. The presence of these substances in the environment brings various problems, including a challenge to wastewater treatment plants and pollution of groundwater and surface water. It leads to long-term environmental, economic and waste management problems. Thus, over the years, the rapid biodegradation of plastic has been a subject of interest in the waste management problems.

The Nobel Prize in Physiology or Medicine, 2016, was awarded to Prof Yoshinori Ohsumi from Tokyo Institute of Technology, Yokohoma, Japan, for his work helped in understanding the molecular mechanisms of autophagy, a process used by most eukaryotic cells to degrade a portion of cytoplasm including damaged organelles, large protein complexes and aggregated proteins in lysosomes. This process of autophagy (self-eating) maintains cellular homeostasis and helps the cell and the organism to survive during periods of stress, such as starvation, by recycling the cellular components to generate amino acids and nutrients needed for producing energy. Autophagy and ubiquitin-proteasome system are the two major protein degradation systems in the cell.

Autophagy is also involved in the development of cancer. First compelling evidence for involvement of autophagy in cancer was provided by the finidng that the gene coding for Beclin 1 (gene BECN) functions as a tumor suppressor in breast and ovarian tumours in humans and is also required for initiation of autophagy. About 40-70\% of breast ovarian tumors have deletion of one copy of the gene coding for Beclin 1 [4].

Augophagy plays an important role in immune response and in the fight against bacteria as Mycobacterium tuberculosis and certain streptococci $[5,6]$. Apart from directly eliminating certain microorganisms through xenophagy, autophagy is also involved in the control of inflammation, activation of adaptive immunity through angigen presentation, and secretion of immune mediators [7].

Autophagy has also been shown to affect lifespan of many model organisms. Various studies done on ageing in these model organisms have shown that longevity promoting interventions like caloric restriction, inhibition of insulin signaling, or administration of rapamycin, at least partly, if not fully, mediate their effects by enhancing autophagy. It is however not known that these interventions will have similar effect in humans on account of lack of my suitable technique to measure autophagic flux in living humans [8] (Figure $1 \& 2$ ).

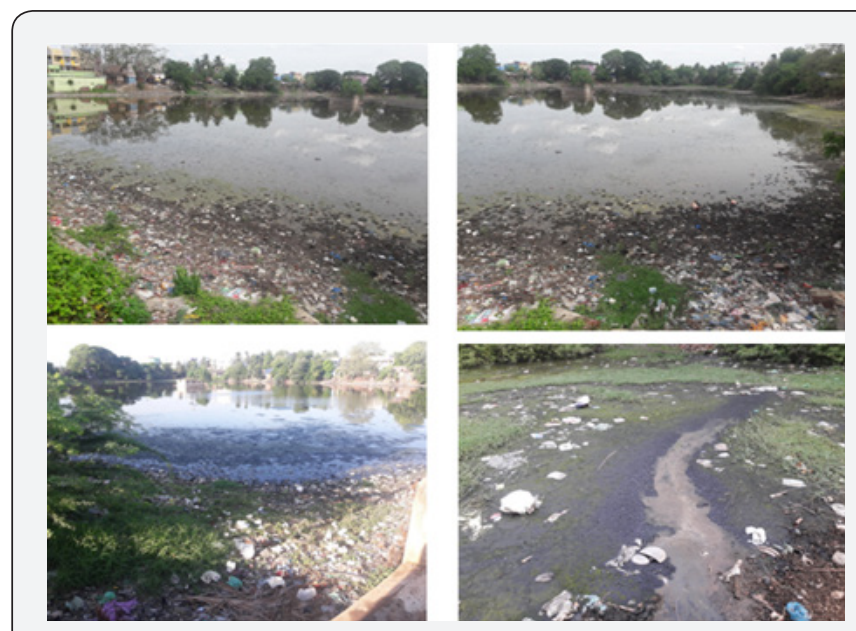

Figure 1: Natural reservoirs is fully occupied by polyethylene bag

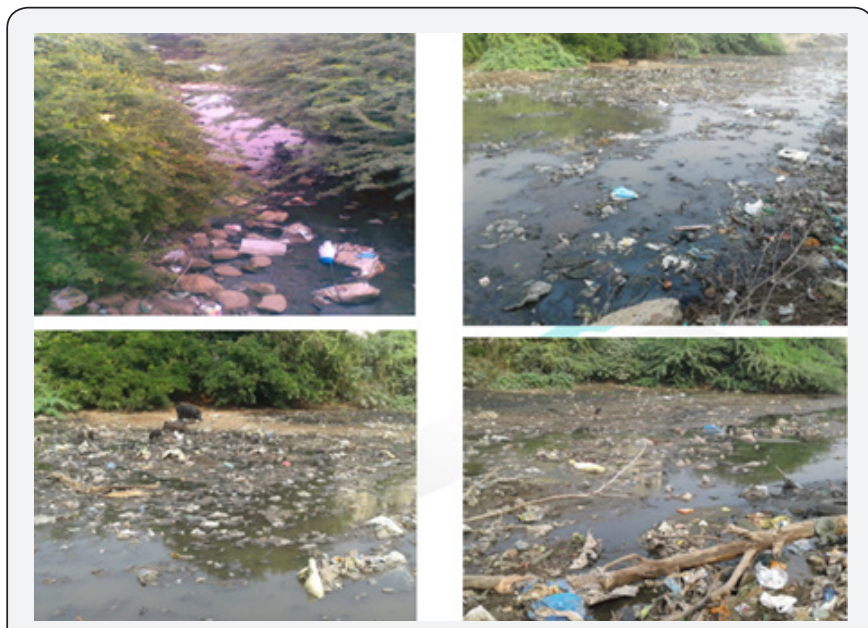

Figure 2: Typicted figure shows mixing of sewage water through canals at southern side of the in which plastic material fully occupied.

\section{Conclusion}

I. Rainfall is decreasing

II. Water resource are dwindling

III. The climate is changing,

IV. Global warming is taking place

In the present investigation, it was apparent that the water quality was affected and it can be inferred from $\mathrm{pH}$, dissolved oxygen, total dissolved oxygen values. Due to entry of animal waste, sewage water, anthropogenic activity of border of Gnanaprakasam pond facing pollution threat. Chlorophyceae and bacillariophyceae members were dominant and these were the indication of organic incidents and pollution tolerating algae. As our country progress towards broader, holistics and ecological 
based management of resources the water quality guidelines must be extended to environment guidelines to protect the pristine ecosystem.

Adverse impact of plastic wastes on our health and environment is also evident, due to their improper disposal and poorly managed recycling system. Polythene bags mainly contain heavy metals such as lead, chromium, cadmium, zinc and copper that can cause alteration of the environment. Plastic wastes dumped on the land are consumed by the grazing fish animals along with grass and other plants and eaten fish other animals and birds through the food chain, resulting in hazardous happenings. Plastics have toxin monomers, which have been linked to cancer and reproductive problems. Due to the latter, there are both external and internal abnormalities in the young ones as a result of alteration of the chromosomes through genes. For examples, unusual number of legs namely four instead of two legs have appeared in hens and unusual numbers of 7 legs instead of four have been noticed in calf and abnormal shape of the face in goat has also been observed.

Autophagy is basically a cell survival mechanism that is induced by stress. Amino acid starvation is one of the most powerful inducers of autophagy. Deregulation of autophagy leads to several diseases including metabolic disorders such as diabetes. Therefore, it is expected that small molecule modulators of autophagy would be useful either alone or in combination with other drugs for therapeutic intervention [9]. Ohsumi's elegant studies in yeast have shown that basic research in model organisms can provide crucial insights relevant for understanding pathological mechanisms in humans. Funding agencies should take a note of it. This is not the first instance where genetic studies in yeast have provided fundamental insights into basic cellular processes relevant for human health and diseases. Earlier genetic studies in yeast have led to Nobel Prize winning discoveries in the area of cell division cycle membrane vesicle trafficking.

\section{References}

1. Masayuki Shimao (2001) Biodegradation of plastics. Curr Opin Biotechnol 12(3): 242-247.

2. Kumar S, Hatha AA, Christi K (2007) Diversity and effectiveness of tropical mangrove soil microflora on the degradation of polythene carry bags. Rev Biol Trop 55(3-4): 777-786.

3. Ohtake Y, Kobayashi T, Itoh S, Asabe H, Yabuki M, et al. (1995) Studies on bio-degradation of LDPE-observation of LDPE films scattered in Agricultural Fields or in Garden soil. Nippon Gomu Kyokaishi 68(11): 808-813.

4. Liang XH, Jackson S, Seaman M, Brown K, Kempkes B, et al. (1999) Induction of autophagy and inhibition of tumorigenesis by beclin. 1 . Nature 402(6762): 672-676.

5. Nakagawa I, Amano A, Mizushima N, Yamamoto A, Yamaguchi H, et al. (2004) Autophagy defends cells against invading group a streptococcus. Science 306(5698): 1037-1040.

6. Guiterrez MG, Master SS, Singh SB, Taylor GA, Colombo MI, et al. (2004) Autophagy is a defense mechanism inhibiting bcg and mycobacterium tuberculosis survival in infected macrophages. Cell 119(6): 753-766.

7. Deretic V, Saitosh T, Akira S (2013) Autophagy in infection, inflammation and immunity. Nat Rev Immunol 13(10): 722-737.

8. Rubinsztein DC, Marino G, Kroemer G (2011) Autophagy and aging. Cell 146(5): 682-695.

9. Levine B, Packer M, Codogno P (2015) Development of autophagy inducers in clinical medicine. J Clin Invest 125(1): 14-24.

\section{Your next submission with Juniper Publishers will reach you the below assets}

- Quality Editorial service

- Swift Peer Review

- Reprints availability

- E-prints Service

- Manuscript Podcast for convenient understanding

- Global attainment for your research

- Manuscript accessibility in different formats

( Pdf, E-pub, Full Text, Audio)

- Unceasing customer service

Track the below URL for one-step submission https://juniperpublishers.com/online-submission.php 